Book Review

\title{
Review of Mills, Sara. (2017). English Politeness and Class. Cambridge: Cambridge University Press. ISBN 9781316336922
}

\author{
Daria Dayter \\ University of Basel \\ Nadelberg 6, Basel 4051, Switzerland
}

For citation:

Dayter, Daria (2019). Review of Mills, Sara. (2017). English Politeness and Class. Cambridge: Cambridge University Press. Russian Journal of Linguistics, 23 (4), 1109-1114. doi: 10.22363/23129182-2019-23-4-1109-1114.

Рецензия

\section{Рецензия на книгу Mills, Sara. (2017). English Politeness and Class. Cambridge: Cambridge University Press. ISBN 9781316336922}

Дарья Дайтер

Базельский университет, Базель, Швейцария

Nadelberg 6, Basel 4051, Switzerland

Для цитирования:

Dayter, Daria (2019). Review Mills, of Sara. (2017). English Politeness and Class. Cambridge: Cambridge University Press. Russian Journal of Linguistics, 23 (4), 1109_1114. doi: 10.22363/2312-91822019-23-4-1109-1114.

The book "English Politeness and Class" is an extended essay on politeness in Britain, its nature and its construals in academic and popular sources. Offering a metaanalysis of the existing politeness theories and illustrating her points with examples from 
blogs and TV, Sara Mills proposes a materialist-discursive approach to analysing interaction which should deal with the deficiencies of earlier approaches. With such a broad scope, the title is somewhat misleading as the issue of class is only one among a plethora of cross-sections - cultural stereotypes, region, age, gender, race, historical period that Mills examines in this book. Mills herself describes her aims as examining "the complex relation between culture and politeness" (p. 1) - a task which far exceeds the limits of class.

The volume consists of six chapters, a bibliography, and an index. The first chapter sets out the purpose of the book as well as the theoretical background, detailing the drawbacks of the existing scholarship that it aims to address. Mills takes a broadly discursive approach to politeness, drawing extensively on Agha's (2007) notion of enregisterment, i.e. the idea that by force of repetition certain linguistic norms become associated with certain values or meanings. After describing traditional approaches to politeness, which are here represented by Brown and Levinson (1987), Mills turns to the well-known critique of this view: the assumption of universality, the confrontational take on all interaction, the equation of indirectness and non-imposition with politeness. It is especially this last aspect that Mills intends to examine in detail, as it is a fallacy that stems from Anglocentric research. The point of contention - that being indirect is not the same as being polite - will be well familiar to Russian readers, where the restrictions on directness are far less severe than in English (Larina 2015). Mills concludes her review of the second and third waves of politeness research with the promise to map out "a more complex approach to the analysis of politeness and impoliteness at a cultural, regional, $\mathrm{CoP}$ [Community of Practice] and individual level" (p. 20).

The second chapter is devoted to the survey of culture classifications that had been offered by the traditional approaches to politeness. These include sorting cultures into positive vs. negative politeness cultures, camaraderie vs. deference, discernment vs. volition, collectivist vs. individualist. Mills challenges these dichotomies on the grounds that no culture is completely homogenous: while they may foreground one or the other use of language, all cultures exhibit both tendencies (p. 35). Although this observation has been made before, e.g. by Wierzbicka (1999), or indeed is the subject of much of the variational pragmatics field, Mills argues that researchers nevertheless fall into the trap of viewing politeness simply as a reflection of underlying cultural norms. In her opinion, making generalisations about cultural groups is "profoundly ideological" (p. 43), and we need to describe those ideologies before we can begin analysing how the interactants draw on them to be understood as polite (or impolite). To proceed, Mills introduces Althusser's (1984) concepts of ideology and interpellation, and Pizziconi and Christie's (2017) indirect indexing. The applicability of these concepts is demonstrated using an example from an interview, an excerpt from a paper on politeness, and the UK government's Respect Agenda.

The third chapter presents a meta-analysis of how English politeness has been characterised overall. For this purpose, Mills surveys three types of data: reports on politeness (both academic and popular), printed and online etiquette manuals, and ques- 
tionnaires on stereotypical attitudes. On the basis of these, Mills outlines several "ideological characteristics of British-English politeness": preference for negative politeness, indirectness, use of 'sorry', self-deprecation, reserve and social awkwardness, and 'stiff upper lip' (pp. 61-70). All of these are illustrated by various examples from the data sources listed above. While quite entertaining, and undoubtedly familiar to those who have come in contact with middle-class Brits, these examples are not presented in a systematic manner and no information is provided concerning data collection. Without knowing the scope or principles of sampling, or the exact nature of the questionnaire, it is hard for the reader to appreciate how telling these results are.

In the remainder of the chapter, Mills observes how all of these stereotypical values in fact draw on middle-class behaviour, that further can be associated with the south of England. This means that, first of all, deviations from this politeness norm would have covert prestige in a different community (e.g. a group of Northerners or working-class youths), but also that speakers may choose to draw on these norms, or deviate from them, at will, depending on whether they want to align or disalign with a particular set of values.

Chapter four is devoted to the title subject of the book: politeness and class. Class, being a notoriously hard concept to define, has often been conflated or confused with other categories, such as ancestry or life style. Mills cites Savage's (2015) work as one example of trying to understand class on a more complex level than simply income. It takes into account individuals' social networks, income and capital, and their engagement with high culture. However, even this "dynamic and delicate view" (p. 82) does not touch on what Mills makes one of the central points of her analysis: how individuals orient to class in interaction. Using examples from popular culture, Mills demonstrates how different ways of speaking are tied in with the notion of class (traditional British politeness being anchored in nineteenth century middle class behaviour). Mills discusses the complex intersectionality of class-related politeness which relates to gender, region, ethnicity, and age. To illustrate this entanglement, she reproduces 25 Manners Every Kid Needs by Age 9, a controversial internet post that first appeared as an article in Parent Magazine in 2011 and was penned by a disgruntled headteacher. It is ostensibly a list of behavioural norms that middle-class families would teach their children as polite and respectful. However, Mills demonstrates that many items on this list in fact represent age ideologies, for example, that adults' needs are superior to children's ("When an adult asks you for a favour, do it without grumbling and with a smile"). This example underscores Mills' point that an individual's linguistic choices concerning im(politeness) are always informed by larger social forces. Finally, in the section titled "The end of civilisation", she addresses the moral panics about the decline of politeness.

In chapter five, Mills puts forward her proposition for a new perspective on politeness: the materialist-discursive approach. In essence, it proposes that "an analysis would focus on the use that interactants make of politeness and impoliteness resources and the work that they seem to be doing with those resources. [...] on the reaction of others to those uses" (p. 113). She then tests her three-stage analysis blueprint by taking 
the ideologies outlined earlier in the book for British politeness, examining the indirect indexicality associated with the ideologies, and eliciting evaluations from recipients using questionnaires. The data for the analysis is the first 15 minutes of one episode of the Great British Bake Off TV show.

The first stage teases out the politeness devices held up in public discourse as national character traits: stiff upper lip, social awkwardness etc. (dealt with in chapter three). In the second stage, Mills analyses the transcript to show how self-deprecation and negative self-evaluation are indeed the resources on which the competitors draw to signal their moral stance in relation to others. For example, one of the competitors states to the camera, "I'm completely gutted. You can't make rookie mistakes in the quarter final". On the surface, such a self-demeaning stance rings false and has no place in the competitive context of the show. But since this resource is ideologically associated with Britishness, it also indirectly indexes niceness and friendliness.

Finally, stage three of the analysis relies on the questionnaire results from Mills' students. The questionnaire "asked interviewees to characterise the language of the participants and the judges, to assess why they chose these styles over others, and to evaluate whether these styles seemed to be particularly British or English" (p. 121). The findings confirm that the students recognise the occurrence of self-deprecation and self-criticism, and judge it to be representative of Britishness. Unfortunately, the lack of specifics on data collection and the method of analysis again is problematic. It would, for instance, make a great deal of difference to the recipient judgement of self-deprecation if the concept of self-deprecation was explicitly made the subject of the questions, or if it came up spontaneously in the answers. The background of the respondents would also be an important variable, since we do not know whether they are British or foreign, whether they had been familiar with the TV show before, whether they had studied linguistic politeness in an academic context, or, indeed, if they were required to watch the show or simply read the transcript.

To round off the book, in chapter six Mills sums up her conclusions and maps out a way forward for politeness research. In agreement with the earlier, 'second wave' work on politeness, she concludes that politeness is "far more complex and messy" than Brown and Levinson (1987) had posited (p. 130). She highlights again that politeness norms are not universally evaluated in the same way across one culture. Individuals can align themselves with or oppose the stereotypical norms. Therefore, "judgements about and definitions of politeness and impoliteness should be recognised for the function they have in establishing positions within a hierarchy" (p. 130).

Mills' book is an up-to-date contribution to recent work in theorizing im(politeness) with culture as a reference point. The volume is argumentative-theoretical and constitutes a reflection on the current state of politeness research and its challenges. Although Mills does make references to the studies that accompanied her work (distributing questionnaires, gathering blogposts and comments), no specific information is given on the empirical aspect. Thus, the book presents a reading of discourse instances by an eminent politeness scholar, informed by her expertise. 
Another area of concern is the apparent disconnect between admitting the contribution of the 'second wave' to understanding politeness, and the way Mills counterposes her new (materialist-discursive) approach to Brown and Levinson's (1987) model throughout the book. For example, the relational work approach by Locher (2004) which Mills recognises for its attention to power in interaction, or Spencer-Oatey's (2000) work on rapport, would be a more logical place of departure. Instead, after a perfunctory mention of these approaches, Mills draws almost exclusively on Agha (2007). However, as it is impossible to do justice to the full depth and breadth of politeness research in 130 pages, it is inevitable that the sketch of existing research is only schematic.

Despite these reservations, "English Politeness and Class" is an impressive work, where Mills in her academic role teases out the ideologies that inform such examples, well known and well loved by the wide public, as the Very British Problems books, the Twitter feed, What the British say and what they mean meme, and The Little Book of Chavspeak. The book will be of interest to researchers who study the interrelations of politeness and culture, and can be used as a basis for discussion in graduate seminars.

(C) Daria Dayter, 2019 cc creative

https://creativecommons.org/licenses/by/4.0/

\section{REFERENCES}

Agha, Asif (2007). Language and Social Relations. Cambridge: Cambridge University Press. Althusser, Louis (1984). Essays on Ideology. London: Verson.

Brown, Penelope \& Stephen Levinson (1987). Politeness: Some Universals in Language Use. Cambridge: Cambridge University Press.

Larina, Tatiana (2015). Culture-Specific Communicative Styles as a Framework for Interpreting Linguistic and Cultural Idiosyncrasies. International Review of Pragmatics, 7, 195-215.

Locher, Miriam (2004). Power and Politeness in Action: Disagreements in Oral Communication. Berlin: De Gruyter.

Pizziconi, Barbara \& Chris Christie (2017). Indexicality and Impoliteness. In Culpeper, Jonathan, Michael Haugh and Dániel Kádár (eds.). The Palgrave Handbook of Linguistic Im/politeness. London: Palgrave, 143-170.

Savage, Mike (2015). Social Class in the 21st Century. London: Pelican/Penguin.

Spencer-Oatey, Helen (ed.) (2000). Culturally Speaking: Culture, Communication, and Politeness Theory. London: Continuum.

Wierzbicka, Anna (1999). Emotions Across Languages and Cultures: Diversity and Universals. Cambridge: Cambridge University Press.

\section{Bionote:}

DARIA DAYTER, Dr., is a postdoctoral researcher and teaching assistant at the English Seminar, University of Basel, Switzerland. Her research interests include the pragmatics of computer-mediated communication, a topic on which she has published the monograph "Discursive Self in Microblogging" (2016) with John Benjamins Publishing, as well as corpus-based discourse analysis, translation and interpreting studies, and linguistic variation in simultaneous interpreting.

Contact information: daria.dayter@unibas.ch 


\section{Сведения об авторе:}

ДАРЬЯ ДАЙТЕР имеет степень $\mathrm{PhD}$, преподает английский язык в Базельском университете, Швейцария. Ее исследовательские интересы включают прагматику компьютерно-опосредованного общения, исследования дискурса на основе корпусного анализа, перевод и языковую вариативность в синхронном переводе. Автор монографии "Discursive Self in Microblogging" (Дискурсивное Я в микроблоге) (John Benjamins Publ., 2016).

Контактная информация: daria.dayter@unibas.ch 